\title{
Logics of fluency in the transformation of the Finnish rail traffic control network
}

\author{
Laura Seppänen ${ }^{\mathrm{a} *}$, Arja Ala-Laurinaho ${ }^{\mathrm{b} * *}$, Päivi Piispanen ${ }^{\mathrm{c} * * *}$ \\ a*Finnish Institute of Occupational Health, Helsinki, Finlândia, \\ laura.seppanen@ttl.fi \\ b**Finnish Institute of Occupational Health, Helsinki, Finlândia, \\ arja.ala-laurinaho@ttl.fi \\ c*** Finnish Institute of Occupational Health, Helsinki, Finlândia, \\ paivi.piispanen@ttl.fi
}

\begin{abstract}
Due to the international demands of competition and organizational changes, the tasks of rail traffic control in Southern Finland have been divided into those run by public agencies and those run by private companies (train operators). The working routines and collaboration have changed during this period of transition. To better understand the reasons for diversity in the actions and solutions of everyday work, this paper examines how fluency, a common objective of networks, is maintained or pursued in network collaboration. The analysis shows how the logics of fluency differ between operative and situational disturbance-handling design levels. We elaborate and discuss the developmental possibilities embedded in the analysis of logics.
\end{abstract}

Keywords

Fluency. Logics. Rail traffic control. Network collaboration.

\section{Introduction}

This paper examines the transitory situation of a networked activity, namely the network of rail traffic control in Southern Finland. Due to the international demands of competition and organizational changes, the previously united tasks of rail traffic control are now divided into those run by public agencies, such as the control of railroads and passenger information, and those run by private companies (train operators) such as the rotation of rolling stock and staff. Therefore, the previous tasks of rail traffic control are now scattered into different centers or organizations. Despite the increasing division of labor, professionals continuously refer to the notion of fluency of traffic. This raised our interest in the different dimensions of 'fluency', and in particular, whether they offer, as they seem to, a uniting common purpose and objective for this safety-critical network.

We empirically examine how the notion of 'fluency' is present in the networked activities, and based on this, interpret the logics with which fluency is maintained or improved. Fluency is defined as the "[...] fluid combination of accuracy plus speed that characterizes competent performance." (Binder, 1996, p. 164). In this paper we investigate the different meanings that practitioners attach to it in their collaborative work. By logic we mean commonly held constellations of beliefs and associated practices that provide rationales for action (Owen-Smith \& Powell, 2008). In institutionalism, logics are the mechanisms through which some actions or decisions seem more legitimated than others. In this paper we use the notion of logics within an activity theoretical framework. Networks, as well as having increasing importance in economic and work life innovations, are crucial environments for the activation of logics.

There are three reasons for investigating logics. First, they help us better understand the reasons for diversity in the actions and solutions of everyday work. In high-reliability network collaboration, common availability of information is not enough; 
the interpretation of this information should also be common (Fields et al., 2005). Familiarity with the other parties' work, its conditions and preconditions, is needed for skilled performance. Second, understanding the logics embedded in practices is important for designing disturbance management and its collaborative procedures. Third, knowledge regarding logics helps us see developmental possibilities and perhaps envision future concepts of networks, enabling us to evaluate different practices and efforts to enhance this development. This method of analyzing logics and their interplay may contribute to the ergonomic study of innovation possibilities in collaborative work activities.

The logics of fluency are analyzed through workshop discussion data. We will analyze fluency specifically in the passenger short-haul traffic of the capital region because here, the developmental need, and thus the need for awareness of logics, is greatest. We found that fluency is understood in different ways at different levels of the network. We describe developmental tensions between the logics both within and between the levels. We pose two research questions: 1 What kinds of logic are embedded in the practical activities of the rail traffic control network? and 2 How can these logics reveal the developmental possibilities of the network? Next, we take a brief look at the history of rail traffic control in Southern Finland.

\section{Network evolution of rail traffic control}

Since 1990, the traditional Finnish Railway Company (VR Group) has undergone several ownership and organizational changes, including the transformation from a state agency into a stateowned company and later into a public company. Thus, transportation services (passengers, freight), track and infrastructure maintenance, national and regional traffic control, passenger information, and other tasks have become more clearly separated into different organizational units and different companies (Table 1).

The Finnish Railway Network Statement describes the access conditions, state-owned rail network, capacity allocation, services supplied to railway undertakings, and the basis on which the infrastructure charge is determined (Finnish Transport Agency, 2013). The Finnish Transport Agency (FTA) is responsible for the infrastructure and traffic control of the rail network of Finland. So far, the FTA has outsourced its regional rail traffic control services to the VR Group according to the provider-purchaser model, but has retained control of the national traffic situation (Table 1). This division of labor slightly resembles the control system in the UK, in which controllers have the job of overseeing the management of large sections of the railway network, whereas signalers are responsible for smaller sections of the railway and manage individual train movements on the section of the network allocated to them. In terms of train or traffic regulation, the roles can be regarded as macro- and micro-management, respectively (Farrington-Darby et al., 2006).

The overall goal of railway control is the fluent, safe and efficient management of the real-time railway traffic, including the infrastructure, rolling stock, staff (drivers, platform staff, train crew, signalers, maintenance gangs, and operators, goods, and passengers). This is challenging for the disturbance management of the fast short-haul traffic of the capital region, especially during organizational and technical changes. Figure 1 shows the division of labor in the network. Designers and senior officials from the FTA, rail traffic managers from the National Traffic Management Centre (NTMC), rail traffic controllers from the Traffic Control Centre (TCC), and information officials from the Information Centre (IC) all contribute to the collaboration. In addition, stock rotation coordinators from the emerging Rail Transport Centre of the VR train operator have had to gradually learn and take over their tasks.

Table 1. Responsibilities and functions of the actors in the rail traffic control network in Southern Finland.

\begin{tabular}{|l|l|}
\hline \multicolumn{1}{|c|}{ Actor } & \multicolumn{1}{|c|}{ Function } \\
\hline $\begin{array}{l}\text { The Finnish Transport Agency (FTA under the Ministry of Transport } \\
\text { and Communications) }\end{array}$ & $\begin{array}{l}\text { ls responsible for the management, development and maintenance } \\
\text { of the Finnish railway network and for the management of overall } \\
\text { train traffic } \\
\text { ls responsible for train traffic control on railroads }\end{array}$ \\
\hline National Traffic Control Centre (unit of the FTA) & $\begin{array}{l}\text { Controls the national traffic situation } \\
\text { Communication with operator (s) }\end{array}$ \\
\hline Traffic Control Centre (VR Group Ltd- private company) & $\begin{array}{l}\text { Controls the local traffic situation (FTA orders ) } \\
\text { Gives adequate traffic information to the lnformation Centre }\end{array}$ \\
\hline Information Centre (VR Group Ltd) & Provides passenger information (FTA orders ) \\
\hline Rail Transport Centre (VR Group Ltd) & $\begin{array}{l}\text { Rotates rolling stock and staff in disturbance situations } \\
\text { Organizes alternative connections }\end{array}$ \\
\hline
\end{tabular}




\section{National Traffic \\ Management \\ Centre NTMC}

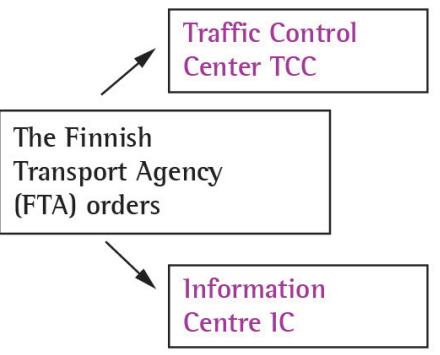

Rail Transport Centre RTC
Task: following the national

traffic situation

Task: following traffic situation, timetabling and giving routes

\begin{tabular}{|l|}
\hline $\begin{array}{l}\text { Task: giving } \\
\text { passage } \\
\text { information }\end{array}$ \\
\end{tabular}

Task: rotating rolling stock and rolling personnel
Goal:

fluent and safe

traffic in

Southern

Finland

Figure 1. Structure and tasks of the rail traffic control network in Southern Finland.

It is important to analyze the entire activity network that contributes to traffic control. As Lenior (Lenior et al., 2006) stated, it is not sufficient to investigate changes of highly automated systems merely from the point of view of cognitive individual performance, as many changes and functions are dynamically interrelated. What is needed is common awareness of the logics involved in the network. In their research on Dutch railways, Lenior et al. (2006) showed, for example, that due to changes in control systems, changes in work and new competence requirements emerged in many different professions and roles involved in traffic control. However, new technical devices and systems offer new kinds of solutions for organizational arrangements and task division to ensure safe and efficient railway traffic. During the period under examination, rail traffic in Southern Finland was facing many changes. It was: 1) preparing for the implementation of a new remotecontrol system for traffic control, 2) moving from local traffic control sites to a large-area remote control center, and 3) renewing its organizational structure and division of labor (Ala-Laurinaho et al., 2009).

Opening the rail traffic market to international competition has resulted in the division of the work tasks of traffic controllers into public and private units. Although rules and tools for competition-enabling rail traffic control are being created, there is still no actual competition of passenger train operators in Finland.
The concept of rail traffic control gradually evolved from local service before the 1980s to regional distant control, and after 2000, towards a dispersed networked collaboration with increased specialization and division of labor (Ala-Laurinaho et al., 2012). Having to be prepared for competition and ongoing neoliberal development are the political and economic imperatives that drive this change. The previous concepts of collaboration in rail traffic control were very much based on common experience, often gained during long careers in the VR company, yielding a rather homogenous local community of rail traffic controllers. Most agree that the future of rail traffic control activity will see the increased use of computerbased information systems, and more separated roles and duties in the network. The central question is: if common experience, formed through experience regarding local rail traffic control, is no longer the uniting factor of collaboration, can fluency be such a connecting notion?

\section{Data and its analysis}

The analysis described in this paper is part of a larger research project that examined the change in the network, collaboration between its activities and wellbeing, and risks concerning change (Ala-Laurinaho et al., 2012; Piispanen et al., 2012). Interviews, observation and videorecording data were collected from different sites. 
Individual rail traffic controllers' work activities and wellbeing were studied and supported by the Developmental dialogue method (Heikkilä, 2012). The research project organized four multi-actor workshops to enhance the common understanding of the development of the network. Being important social events, the workshops allowed the different individual representations of the participants to emerge and favored their integration. They also linked operators' analysis of their activities to the future design of the network (see Duarte \& Lima, 2012). When analyzing the workshop data we became interested in the different dimensions of fluency.

\subsection{Workshop data}

The fourth and last of these workshops, for anticipating future collaboration in the disturbance management of the diverging network, was organized in November 2010. As proposed by the network actors, it focused on the future collaboration between rail traffic controllers and the personnel of the train operator VR Group called stock rotation coordinators. These coordinators manage the rolling stock of trains, particularly in disturbance situations. Rotating the stock is one of the most difficult tasks to separate from the previous work of rail traffic control, especially in the intensive short-haul passenger traffic of the capital region. The aim was also to discuss a new potential collaborative tool - conjoined action cards - for handling disturbance situations. A total of 19 people from the network participated in the workshop: five rail traffic controllers, three stock rotation coordinators, one person from the passenger $1 \mathrm{C}$, two superiors from the VR Group, five senior inspectors and designers from the FTA, and three researcher-facilitators. The detailed analysis of this paper is based on the discussion data in the last workshop, because this was where the diversity of dimensions of fluency was most pronounced. Being the last workshop, the main findings from previous workshops were embedded in it. The different dimensions of fluency are simultaneously present and condensed in the workshop discussion data, which is difficult to obtain in a field-level activity analysis of 1T-mediated and multi-located network collaboration. The other data and findings of the project have helped us in the formulation and interpretation of the research problem (see Ala-Laurinaho et al., 2009, 2012; Seppänen et al., 2011).

The fourth six-hour workshop, designed jointly by researchers and the network participants, began with a presentation in which a regional traffic manager from the FTA described the current projects for improving situation awareness. After this, the participants were divided into three groups, which each modeled one complex disturbance situation. The disturbance situations; a broken train wagon, and limited railroad capacity between two stations, were real and selected by the rail traffic controllers themselves. The groups were to depict and discuss the information flows, anticipation and decision-making involved in their solutions for the disturbance. The presentations of the groups were collectively discussed and their solutions were placed in a two-dimensional framework depicting the development of the network. Later, based on the modeling of the disturbances, the groups discussed how action cards (see section 5.2 below) would help solve the disturbances, and what they should contain. At the end, reduction plans that are used in longer-term disturbance situations were discussed. The workshop methods used were similar to narrative simulation (Daniellou, 2007).

\subsection{Method}

The analysis focuses on the common discussions between the participants. After transcription, the data was divided into episodes named according to the topic of discussion; 97 episodes altogether. We identified topics in which dimensions of fluency or future expectations of fluency could be observed. For the purpose of this paper, we specifically chose the topics $(n=19)$ in which the dimensions of fluency were closely linked with collaboration between different groups of actors.

This analysis leans on two theoretical approaches: activity theories, in particular cultural-historical activity theory, CHAT (Engeström, 1987); and institutional logics, or logics of action. CHAT provides a developmental approach that states that the dynamic object of activity directs the logic of work, and that actors need to innovate in order to put the new network model into practice. CHAT also equips us with the notion of an activity concept, meaning the pattern of production and service entity, including, for example, financial principles, technology, the division of labor, management systems, and learning systems. In expansive transformations of work, the basic logic and structure of the production activity changes; in other words, the activity concept is transformed. A concept of activity means a principle that has evolved in the past or is still evolving, and which satisfies a societal need (Virkkunen, 2007). In this paper, we are interested in the period of transition in which an old concept of rail traffic control is gradually transformed into a new networked concept, which is still partly unknown.

Logics constitute the rules and conventions, or "organizing principles" of a particular domain. This is a notion developed in institutionalism (Barley \& 
Tolbert, 1997; Thornton \& Ocasio, 2008). Logics make networks meaningful features of social and economic worlds by disciplining (though not determining) the formation and implications of relationships and networks. Logics are the mechanisms through which some actions or decisions seem more legitimated than others. When used in activities, they may be similar to the notion of a world (Béguin \& Cerf, 2004; Daniellou, 2007). The notion of an institutional logic is particularly useful because it highlights the stable, institutionalized and sometimes constraining character of logics. Moreover, logics may be used to analyze activity concepts.

Tiina Kalliomäki-Levanto (2009), examining the external goals of work, defines fluency as the progress of work without breaks or ruptures, while experiential fluency is defined as

[...] an expectation of planned, effective, and goal-oriented flow of work." (Bergström, 2011, p. 5). Binder (1996, p. 164) qualifies fluency as the "fluid combination of accuracy plus speed that characterizes competent performance

and states that its advantage is that many people understand it intuitively or metaphorically. The notion of fluency is not much used when studying knowledge-intensive work (Bergström, 2011) such as rail traffic control. In our paper, the notion of fluency is above all a popular notion used by the network actors: it is of interest to us because it may be a characteristic of the potential common object of the rail traffic network.

We next show and interpret 13 topics containing dimensions of fluency, after which we condense them into more general logics of fluency. Before this, however, in order to illustrate the network situation in which the actors worked, we briefly describe some problems expressed by the participants.

\section{Problems experienced in networking}

As explained above, rail traffic control was going through many changes at the time of the study. There was a great deal of uncertainty in this transitory phase. This uncertainty was considered a constraint for developing new practices: It's difficult to plan collaboration because we don't know the rules yet. Another problem experienced was the lack of understanding, or misunderstandings in the interaction between network partners (Excerpt 1).

\section{Excerpt 1.}

Rail traffic controller: [...] we are different kinds of people, we see the situations in different ways, we make decisions in different ways. Some people can make a decision in two seconds, others in two minutes. And when the opposition rises, and the choices clash, it can be quite a difficult situation. The two sides do not understand each other. They can mean the same thing, but do it in a different way and one may know something essential that the other does not understand. And this situation may escalate precisely because the information does not come together. I feel that the biggest factor now is that we don't know what we're talking about.

The interaction problem above was due to the unclear power relation between rail traffic controllers and stock rotation managers (see Topic 6, Table 2, Section 5). From the perspective of strategic design, the variation in rail traffic control practices and decisions was problematic because, in order to be prepared for possible future competition between operators, transparency and accountability had to be increased (see Topic 11, Table 3, Section 5). A discussion about preparation plans for expected, wide-ranging, longterm disturbance periods revealed that the division of labor was also unclear in strategic design, not only on the operational level of this public-private network. This problem was not explicitly expressed in the workshop. As regards ideas for learning and development, organizational hierarchy and the emphasis on decision structures were considered obstacles to new innovative suggestions and positive collaboration.

Many developmental projects were being carried out to solve these and other organizational transition issues. In the following section we examine the dimensions of fluency in their practical contexts found in the workshop data.

\section{Fluency in the rail traffic control network}

Table 2. Topics containing dimensions of fluency at the operative level of rail traffic control.

\begin{tabular}{|l|}
\hline 1 The 'shouting system' of the old control center works well \\
\hline 2 The planned solutions do not work in chaotic situations \\
\hline 3 Cancelling trains for solving disturbances \\
\hline 4 Multiple ways of solving a stock disturbance \\
\hline 5 Feeding the solution to a colleague \\
\hline $\begin{array}{l}6 \text { ln the future model, decision-making will go through stock } \\
\text { rotation coordinators }\end{array}$ \\
\hline 7 Helping others in the network \\
\hline $\begin{array}{l}\text { E Enhancing common understanding through interaction, a } \\
\text { meeting after disturbance situations }\end{array}$ \\
\hline 9 Proposing and sharing new ideas \\
\hline
\end{tabular}

Table 3. Topics containing dimensions of fluency at the level of designing situational disturbance-handling.

\begin{tabular}{|l|}
\hline 10 Clear play \\
\hline 11 Action cards: Management of disturbances by diminishing \\
'personal handwriting' \\
\hline 12 Action cards: Flexibility rather than detail \\
\hline 13 Experimenting with action cards \\
\hline
\end{tabular}


During the analysis it became clear that the themes and topics discussed belonged to different levels of the network. We list the levels of the operative rail traffic control and of the design of situational disturbance management. Tables 2 and 3 show the topics in which dimensions of fluency appear. After each table we explain the topics by paying special attention to the question of fluency as it is reflected in the network collaboration. Moreover, we abstract the embedded logics in order to gain more generalized knowledge about the transitory situation of the network (Table 4).

\subsection{Operative level of rail traffic control}

In the workshop discussion, the majority of the analyzed topics were linked with decision-making, the division of labor, and interaction in disturbance situations. Physical environments, information systems and learning were also discussed. Table 2 shows the topics in a condensed form; they are described in more detail below.

1. The 'shouting system' of the old control center works well. In disturbance situations, the previous way of working among rail traffic controllers, and contact between them and the passenger information unit, was based on oral communication. This was enabled by their common location as well as by the layout structure within the control hall. This model was to change, as these functions would be moved to a new control center, where most information would be shared through information systems rather than orally. The new principle would be put into practice by learning the new information systems in the new center. The change from oral to information system-mediated communication was experienced as a major transformation and considerably changed the forms of collaboration. 'Shouting' follows the logic of resorting to oral communication. We may call it a collective manifestation of a previous craft-like way of controlling rail traffic. The topic also shows that the material artifacts used mediate the ways of collaboration, and that the immediate contact provided by shouting has been an important community-building resource and support for rail traffic control activity.

2. Planned solutions do not work in chaotic situations. Some major occurrences, such as the exceptionally abundant snowfalls in the winter of 2009-2010, cause chaotic situations in which rail traffic controllers have to proceed on a moment-to-moment basis and planned solutions are of no help. This is the experience and message of rail traffic controllers to the designers planning the solutions, and shows that strengthening vertical collaboration between them will be a challenge. Of course, chaotic situations are not good for fluency or safety, or for the well-being of employees, and should be avoided. We conclude that the fluency prevalent in a chaotic situation is very different to that in a controlled disturbance situation. The practitioners' individual coping with the disturbances is particularly important in chaotic situations.

3. Cancelling trains for solving disturbances. A stock rotation coordinator viewed this logic, used by rail traffic controllers, as undesired (Excerpt 2).

\section{Excerpt 2: \\ Stock rotation coordinator: [...] if we now somewhat easily and quickly bypass [the disturbance situation] by cancelling the train and if we [the stock rotation coordinators] have another solution, if there are no immediate reasons, traffic control should not turn it down, unless there was a particular reason.}

This topic reveals two dimensions of fluency: first, fluency by cancelling trains, and second, fluency as the extensive supply of trains. Traffic with fewer trains is easier, more fluent and safer to manage than making complex arrangements for maintaining a schedule. The stock rotation coordinator felt that the rail traffic controllers cancelled trains too easily - he called the using of this logic 'bypassing' the situation. He favored the second perspective, that of fluency by running as many of the scheduled trains as possible, which is a passenger-friendly perspective that supports the business affairs of the train operator (i.e. fluency for passengers).

4. Multiple ways of solving a stock disturbance. When disturbances concerning broken wagons were discussed, it became evident that a wide range of possible solutions were in use. A broken wagon could be substituted by another wagon if there was one nearby, or the train in question could depart on schedule with fewer wagons. One may also set a time frame for determining the wagon's defect, after which the solution is selected accordingly. All these solutions require different kinds of contact and communication between rail traffic control, train personnel, passenger information, stock rotation, and others. The work of rail traffic controllers had so far been called 'art', meaning that intuition and craft are important. It seems that fluent rail traffic requires multiple solutions to be used in a flexible way. Indeed, flexibility is needed because, as indicated by Weick \& Sutcliffe (2007), the quality and type of disturbances can never be totally anticipated. The workshop discussion continuously returned to the flexibility issue for solving disturbances and making decisions. Here, we see flexibility as a general logic of fluency.

5. Feeding the solution to a colleague. As we saw in Section 3, the changing division of labor made mutual interaction problematic. In this topic, a rail traffic controller introduces a practice in which 
someone else, without them noticing, accepts a solution as if they had invented it themselves. This is particularly relevant when a rail traffic controller knows stock rotation, but the newcomer stock rotation coordinators, still without the know-how, have to make decisions concerning wagons and the locomotives of the trains. This is a roundabout way to hierarchy, which simultaneously helps maintain good relationships. On a general level, this logic of fluency may be called a skilled negotiation for smooth collaboration.

6. In the new model, decision-making will go through stock rotation coordinators. A stock rotator argued that it is they who make the decisions about the stock of the trains, and not the rail traffic controllers. As Excerpt 3 shows, the controllers did not agree with this.

\section{Excerpt 3.}

Stock rotation coordinator: We should do the work together, so that each can give his own opinion, and somebody comes to a decision - who this should be though, is still unclear. The stock rotation coordinator makes the decision, because he is responsible for the stock of the train operator $V R$, and how to place the wagons. Senior inspector: How do you see it? Who should it be? Stock rotation coordinator: I think that the stock rotation coordinator should make the decision after the transition period, because he is responsible in the train operator company for the wagons. Rail traffic controller: 1 disagree. Senior inspector: Me too, it's not necessarily that clear. We don't have to sit thinking about it, a smart solution is the outcome of tight collaboration and common understanding. And credibility is involved as well. A rail traffic controller should trust the partner and his ideas. It would be good if the stock rotation controller held the cards and had an understanding of the rhythm of the rotation. Great, if this is the case. But on the other hand, a stock rotation coordinator alone cannot know what the traffic situation is.

The stock rotation coordinators indeed make the decisions and carry the responsibility on the level of the VR operator. However, on the level of the whole network, the decision concerning the stock depends on the fluency of the overall traffic situation and on trust in collaboration. We may call this a hierarchy in decision-making, meaning that the overall traffic situation has primacy over partial solutions. This topic also shows that the question of hierarchy is still not clear to all, that collaboration is fragile, and that the hierarchy in decision-making is part of the fluency.

7. Helping others in the network. As the controllers and train operator personnel work for different organizations, the question arises as to whether they are allowed to break organizational boundaries by helping other partners. The answer is that rail traffic controllers can perform the tasks of the operator if they have spare time. This helping may be related to voluntarism, a sort of semi-informal self-organizing, in which managing the contents of work is linked to the collective responsibility of the global networked activity (Knorr-Cetina \& Bruegger, 2001). The sense of community prevalent in the old concept supports this voluntarism. We may name this logic, with which fluency is maintained, communal voluntarism.

The two last topics refer to learning and development.

8. Enhancing common understanding through interaction. Increasing common understanding was considered essential. Interacting and dedicating time and space to crossing boundaries across organizations was deemed necessary through, for example, having a meeting after disturbance situations, working more closely together in the same space, or through teamwork. In practice it was not easy to dedicate time to interaction and developmental purposes because of the three-shift system and because rail traffic control was part of the cost-efficiency program of the state. The fluency logic embedded here can be called interaction for shared understanding.

9. Common practice of proposing and sharing new ideas. It was suggested that any individual worker might make suggestions and deliver know-how to others; however this was hindered by the importance assigned to decision-making and authority (see the problems described in Section 3). There was a desire for an open environment that would enable talking about mistakes and learning from them. This, together with Topic 2, can be interpreted as practitioners' suggestions for strategic design and management.

To summarize the dimensions of fluency on the operative level of rail traffic control: Fluency, especially in chaotic rail traffic situations, is considered to pertain to the progress of each practitioner's own work. Fluency is also conceptualized as flexibility, meaning that practitioners should have enough room to maneuver and apply different solutions. Fluency is thought to be maintained by an extensive supply of trains, and to mean smooth interaction in network collaboration. Promoting fluency was conceptualized as enhancing common understanding, in different ways, between the network partners. The previous object of rail traffic control was to ensure good traffic conditions on railroads. As is seen in many of the topics above, the change and increasing division of tasks in the network made the object also include the network and its collaboration. The network becomes a resource for situation awareness in managing dynamic risks (Rogalski, 1999). 


\subsection{Level of designing situational disturbance-handling in rail traffic control}

We illustrate the fluency on this level using four topics (Table 3).

10. Clear play. The train operator VR was about to create a new center for many kinds of train-related activities such as stock rotation and passenger information. It was estimated that both the appearance of this new center and the division of tasks between rail traffic controllers and stock rotation coordinators would considerably affect the networking of activities, and therefore, a new frame was needed. We may interpret 'clear play' in terms of increasing standardization; however it may also mean a consciousness of the shared way of working and collaborating in the network. Clarity is thus not the opposite of flexibility, but a common awareness of the network concept, whatever it might be. We call this logic of fluency a common frame of action.

Action cards are an umbrella notion for Topics 11-13. They mean guidelines, planned in advance, for handling a certain local disturbance situation concerning, for example, a certain piece of railroad. A specific action card, defining the measures to be taken, is made for each group of partners involved. The idea of action cards was taken from the Norwegian rail traffic control system in the Oslo region. It was considered a suitable tool for assuring fluency in the diverging network around rail traffic control. By discussing action cards as promising artifacts, the attempt was to contribute to their instrumental genesis (Folcher \& Rabardel, 2005).

The use of action cards starts when an actor in the network observes something that deviates from the norm, and which might indicate a disturbance. Then the observer, which can be anyone in the network, shares this information with the group of actors related to this kind of disturbance. After this, the network agrees on a particular set of action cards to be applied. Somebody in the network has formal responsibility for this decision, "but it is a formality only". Each actor has his or her own action card concerning the same disturbance, which indicates the steps to be taken.

\section{Management of disturbances by diminishing} 'personal handwriting'. The rationale for the action cards, from the perspective of the strategic design of the network, is to make rail traffic control more foreseeable to others by diminishing the variation of action in the network. In this sense, this topic directs to standardization (Excerpt 4).
Excerpt 4.

Senior inspector: ...l suppose we should simply say that this train just will not move. We don't look into the details, whether [the broken wagon] is at this or that end or in the middle, whether it'll move or not. The train just won't move. This has consequences. Rail traffic controller: Or, would it be worth describing different alternatives here, as if the first wagon is defective... Senior inspector: It gets too complicated. We don't have time. There's no time for adjustments, we're talking about minutes here.

12. Flexibility rather than detail. The preferred degree of the standardization or flexibility of the future action cards was discussed at length. Some argued that the action cards would not work in the hectic short-haul traffic of the capital region of Helsinki. Flexibility was considered better than detail. This is one of the crucial issues in moving the activities of rail traffic control towards the new network concept. Common frames, as stated in the guidelines of the action cards, can be standardized. If they are general (rather than detailed), they also enable detailed situational maneuvering when necessary. We call this logic of fluency limited flexibility.

13. Experimentation with action cards. Collective learning, and experimentation as part of it, is of central importance in the rail traffic control network's current situation. There were many views on what form the action cards should take. The idea was to outline several alternative sketches of action cards by imposing actual tacit procedures into templates. The best action card could be found by experimenting with different sketches. This topic integrates standardization and flexibility, but also introduces the general logic of experimentation for fluency.

Because the network of rail traffic control is in a continuous and complex process of change, it is difficult to manage the change by designing a ready-to-use operations model or concept of activity. Experimentation can be seen as "[...] acting, without being able to foresee everything, in order to know." (Clot, 2009, p. 287). The new concept has to be created step by step by both horizontal and vertical development collaboration. Weick \& Sutcliffe (2007) propose a "small wins strategy": supporting and enabling the experimentation of new practices, and evaluating their functioning.

Contrary to the previous level of operative rail traffic control, we see an increased need for simplification and standardization in order to help the fluency and foreseeability of the function. Fluency is conceptualized as clear play (either standardization or common awareness of the concept as a common way 
Table 4. Logics according to which fluency is maintained or promoted in the short haul passenger traffic of Southern Finland.

\begin{tabular}{|l|}
\hline 1. Resorting to oral communication. \\
\hline 2. Coping of individual workers in disturbance situations. \\
\hline 3. Cancelling trains. \\
\hline 4. Running as many trains as possible according to schedule. \\
\hline 5. Flexibility. \\
\hline 6. Skilled negotiation for smooth collaboration. \\
\hline 7. Hierarchy in decision-making. \\
\hline 8. Communal voluntarism. \\
\hline 9. Interaction for common understanding. \\
\hline 10. Sharing of ideas. \\
\hline 11. Common frame of action. \\
\hline 12. Standardization. \\
\hline 13. Limited flexibility. \\
\hline 14. Experimentation. \\
\hline
\end{tabular}

of working) and as simplification and standardization of the disturbance-handling procedures. Action cards are a major tool for this purpose. Fluency may mean flexibility, but within certain confines of standardization only. Experimentation is a way of developing the action cards.

We can now list the logics of fluency found in the data (Table 4).

\section{Contribution of logics to developing the network}

Table 4 shows the great diversity of the logics of fluency. Fluency indeed has many different meanings in this complex network. Moreover, many of these logics are interdependent. According to Owen-Smith \& Powell (2008, p. 600), the linkages among logics for action are the central, defining characteristics of organizations.

The Cultural-historical activity theory claims that the potential for development lies in the dialectics between the logics. This directs us first to focus on the logics with tension between them. As we are interested in temporal change and development, we focus particularly on the pairs or groups of logics which, based on our understanding of the transitory situation of the network (section 2), are likely to go through dynamic changes. Launis \& Pihlaja (2007) studied the asynchronies between competing activity concepts that cause disturbances and discontinuities at work and thus challenge the well-being of employees. We believe that it is the tensions between logics that cause these asynchronies.

1. Interplay between hierarchy in decision-making and communal voluntarism. As argued by Diefenbach \& Sillince (2011), hierarchical order, either formal or informal, is persistent in all forms of organization. Informal hierarchy in particular emerges in network forms of organization, based on an informal principle of communicative dominance. This may not be recognized. In our case, it is the overall view of the traffic situation of the traffic controllers that legitimates the hierarchy. We learn here that the question of hierarchy is relevant and that the forms of hierarchy of the network should be reflected upon critically (Diefenbach \& Sillince, 2011). Both hierarchy and communal voluntarism are important.

2. Interplay between cancelling trains and running as many trains as possible. Although tension exists between these two logics, they are both necessary. The first emphasizes safety which may be promoted more by the public interest of controlling railroads. Keeping up the train schedule is important for all, but particularly important for private train operators. It is crucial that the public and private actors understand the logics behind each other's functions.

3. Interplay between standardization and flexibility. This is a classic dilemma in organization studies, and a more standardized and simplified concept is required in the network of rail traffic control. Standardization decreases clashes and ruptures in interaction, if there is common agreement on the procedures used. A more standardized way of working was found by creating and implementing the use of action cards. The idea of the action cards was to experiment with alternative templates in order to find suitable ones for a particular type of situation. Here, the way in which the action cards are used is important: if guidelines are taken as rules, we run into difficulties; they should be used as tools in the activity that is managed by a certain actor (Norros \& Savioja, 2004). The notion of knotworking (Engeström, 2008) aptly reflects this ad hoc, boundary- and rule-crossing way of working that should be allowed in the use of action cards (Ala-Laurinaho et al., 2012). Collaborative experimentation with action cards seems an excellent potential solution for integrating standardization and flexibility.

In our analysis of the topics, we focused on two levels of the network, namely, operative rail traffic control (Topics 1-10), and the design of disturbance management (Topics 11-14). Standardization is the aim of strategic design, while flexibility is desired in operative rail traffic control. Thus, the interplay between these two logics seems to be crucial in the dialogue between operative and strategic levels. In the case of diverging tasks it is important that information about situations that require flexibility is included in design. In practice, this implies a need for collaboration between strategic design and operative rail traffic control.

The controllers had learned to master different kinds of disturbance situations in their own individual ways, which meant variation in the solutions applied. 
According to strategic design, this would not be possible in the future because of the need for transparency and objectivity towards future train operator competitors. In our interpretation, this transforms the understanding of fluency. The object of train traffic control activity becomes wider and more complex: it still includes enabling traffic for trains and passengers travelling on railroads, and managing the collaboration with network colleagues, but now also comprises the societal meaning of assuring the transparent and impartial functioning of the whole network, in a way that can be seen and assessed by authorities.

\section{Discussion and conclusion}

In this paper, we have analyzed topics in which the dimensions of fluency are embedded, through workshop discussion between the multiple actors of the short-haul passenger rail traffic control network. By distinguishing the levels of operative rail traffic control and the level of designing its situational disturbance-handling, we are able to see that the logics vary not only within a level, but also between levels. The use of these logics to promote confrontation and debate among network actors may lead to shared interpretations of the work determinants (Daniellou, 2007).

In Section 2 we asked if the notion of fluency could be a uniting factor in the new network constellation of rail traffic control. Based on our analysis, the answer is yes, on the condition that the diversity, tensions and interplay of the logics embedded in the fluency are considered.

The above analysis of logics has given us an understanding of the state-of-the-art level and complexity of the collaborative network. Awareness of the different existing logics may promote fluency in network collaboration. Rather than being interpreted in a normative way, tensions should be seen as sources of ideas for development and innovation. We emphasize that reflection of the competing logics can help practitioners and designers find many different solutions and innovations to experiment with. While the dimensions and logics found are local and particular, the method of their analysis may guide generalization and transfer from one study to another. Moreover, with contradictory logics we may create conceptual models (Béguin \& Cerf, 2004), or concepts of activity (Virkkunen, 2007) for network collaborations. However, this requires further research.

\section{References}

Ala-Laurinaho, A., Launis, K., Piispanen, P., Raaska, T., \& Sauni, S. (2009). Analysis of changing traffic control work: disturbance handling as a shared task of a network. In Proceedings of the 17th World Congress on Ergonomics: Changes, Challenges and Opportunities, Beijing, China.

Ala-Laurinaho, A., Heikkilä, H., Piispanen, P., \& Seppänen, L. (2012). Verkostomuutos, solmutyöskentely ja työhyvinvointi raideliikenteenohjauksessa. Sujuthankkeen loppuraportti. Liikenneviraston tutkimuksia ja selvityksiä 17/2012. Helsinki: Liikennevirasto. Retrieved from http://www2.liikennevirasto.fi/julkaisut/pdf3/ lts_2012-17_verkostomuutos_solmutyoskentely_web. pdf

Barley, S. R., \& Tolbert, P. S. (1997). Institutionalization and structuration: studying the links between action and institution. Organization Studies, 18(1), 93-117. http:// dx.doi.org/10.1177/017084069701800106

Béguin, P., \& Cerf, M. (2004). Formes et enjeux de l'analyse de l'activité pour le conception des systèmes de travail. @ctivités revue éléctronique, 1(1).

Bergström, H. (2011). Fluency experiences in knowledgeintensive individual work and collaboration. Helsinki: Aalto University School of Science. Retrieved from http://lib.tkk.fi/Diss/2011/isbn9789526041414/ isbn9789526041414.pdf

Binder, C. (1996). Behavioral fluency: evolution of a new paradigm. Behavior Analyst, 19(2), 163-197. PMid:22478257 PMCid:PMC2733609.

Clot, Y. (2009). Clinic of activity: the dialogue as an instrument. In A. Sannino \& H. Daniels \& K. Gutiérrez (Eds.), Learning and expanding with activity theory (pp. 286-302). Cambrigde: Cambridge University Press.

Daniellou, F. (2007). Simulating future work activity is not only a way of improving workstation design.@ctivités revue éléctronique, 4(2), 84-90. Retrieved from http:// www.activites.org/v4n2/v4n2.pdf

Diefenbach, T., \& Sillince, J. A. A. (2011). Formal and informal hierarchy in different types of organization. Organization Studies, 32(11), 1515-1537. http://dx.doi. org/10.1177/0170840611421254

Duarte, F., \& Lima, F. (2012). Anticiper l'activité par les configurations d'usage : proposition méthodologique pour conduite de projet.@ctivités revue éléctronique, 9(2), 22-47. Retrieved from http://www. activites.org/sommaires/v9n2.html

Engeström, Y. (1987). Learning by expanding. An activitytheoretical approach to developmental research. Helsinki: Orienta-Konsultit.

Engeström, Y. (2008). From teams to knots: activitytheoretical studies of collaboration and learning at work Cambridge: Cambridge University Press. http://dx.doi. org/10.1017/CB09780511619847

Farrington-Darby, T., Wilson, J. R., Norris, B. J., \& Clarke, T. (2006). A naturalistic study of railway controllers. Ergonomics, 49 (12-13), 1370-1394. PMid:17008261. http://dx.doi.org/10.1080/00140130600613000

Finnish Transport Agency - FTA (2013). Railway network maintenance. Helsinki. (Transport Infrastructure data of the Finnish Transport Agency 3/2011). Retrieved from http://portal.liikennevirasto.fi/sivu/www/e/maintenance/ railway_network_maintenance

Fields, B., Amaldi, P., \& Tassi, A. (2005). Representing collaborative work: the airport as common information space. Cognition, Technology and Work, 7, 119-133. http://dx.doi.org/10.1007/s10111-005-0177-3 
Folcher, V., \& Rabardel, P. (2005). Hommes, artefacts, activités: perspective instrumentale. In P. Falzon (Ed.), Ergonomie (pp. 251-268). Paris: Presses Universitaires de France.

Heikkilä, H. (2012). Understanding and promoting work careers and well-being in changing work: new insights from developmental work research and the developmental dialogue method. Helsink: European Group for Organization Studies.

Kalliomäki-Levanto, T. (2009). Keskeytykset ja katkokset työn etenemisessä: edeltävät tekijät, epäjatkuvuusolosuhteet ja niistä selviytyminen tietotyössä. Helsinki: Työterveyslaitos. (Työ ja ihminen Tutkimusraportti, 36).

Knorr-Cetina, K., \& Bruegger, U. (2001). Transparency regimes and management by content in global organizations: the case of institutional currency trading. Journal of Knowledge Management, 5(2), 180-194. http://dx.doi. org/10.1108/13673270110695487

Launis, K., \& Pihlaja, J. (2007). Changes in production concepts emphasize problems in work-related well-being. Safety Science, 45, 603-619. http://dx.doi.org/10.1016/j. ssci.2007.01.006

Lenior, D., Janssen, W., Neerinx, M., \& Schreibers, K. (2006). Human factors engineering for smart transportation: Decision support for car drivers and train traffic control. Applied Ergonomics, 37, 479-490. Pmid:16765905. http://dx.doi.org/10.1016/j.apergo.2006.04.021

Norros, L., \& Savioja, P. (2004). Ihmisen ja tekniikan välisen vuorovaikutuksen toimivuuden arviointi monimutkaisissa tietointensiivisissä töissä. Työ ja ihminen, 18(3), 110-112.

Owen-Smith, J., \& Powell, W. W. (2008). Networks and institutions. In R. Greenwood, C. Oliver, K. Sahlin
\& R. Suddaby (Eds.), Handbook of Organizational Institutionalism. London: SAGE Publications. http:// dx.doi.org/10.4135/9781849200387.n26

Piispanen, P., Ala-Laurinaho, A., Heikkilä, H., \& Seppänen, L. (2012, May). With Activity Theory to better understanding of risks: the case of rail traffic control network. In Proceedings of the 10th International Conference on Occupational Risk Prevention (ORP 2012), Bilbao, Spain. PMid:22886999 PMCid:PMC3485915.

Rogalski, J. (1999). Decision making and dynamic risk management. Cognition, Technology and Work, 1(4), 247-256. http://dx.doi.org/10.1007/ s101110050021

Seppänen, L., A. Ala-Laurinaho, Heikkilä, H., \& Piispanen, P. (2011). Kuinka verkoston lähikehitystä tutkitaan? Esimerkkinä rautateiden liikenteenohjaus. In Työelämän tutkimuspäivät 2010: Työn tuottavuus + työelämän laatu - mahdollisuus vai mahdottomuus? (pp. 152164). Tampere: Tampereen Yliopisto. (Työelämän tutkimuspäivien konferenssijulkaisuja, 2/2011).

Thornton, P. H., \& Ocasio, W. (2008). Institutional logics. In R. Greenwood, C. Oliver, K. Sahlin \& R. Suddaby (Eds.), Handbook of Organizational Institutionalism. London: SAGE Publications. http://dx.doi. org/10.4135/9781849200387.n4

Virkkunen, J. (2007). Collaborative development of a new concept for an activity. @ctivités revue éléctronique, 4(2), 158-164.

Weick, K. E., \& Sutcliffe, K. (2007). Managing the unexpected: resilient performance in an age of uncertainity. John Wiley \& Sons. 